exceeds $£ 12,000,000$. Research on mental disease has been very much neglected in the past. The object of the work now being carried out at Cardiff is to find out more about the working of the brain and nervous system in health and disease, so that this knowledge can be applied to the treatment of mental disorders of every kind. The lines of research now in progress include biochemical work on the enzymes in the brain, and work using the radioactive 'tracer' technique. Clinical research is also being carried out on problems related to schizophrenia, epilepsy and senility.

\section{Capper, Pass Awards for Metallurgy}

Messrs. Capper, Pass and Son, Ltd., of Bristol, have offered the Institution of Mining and Metallurgy and the Institute of Metals $£ 200$ a year for seven years, to be applied as follows : (a) $£ 100$ a year for one or more awards for papers on some aspect of nonferrous extraction metallurgy; (b) $£ 100$ a year for one or more awards for papers relating to some process or plant used in the extraction or fabrication of non-ferrous metals. Both awards are for persons engaged full-time in industry or practice. The Councils of the Institution of Mining and Metallurgy and of the Institute of Metals have appointed a joint adjudicating committee which will examine annually all papers published by both societies; no special applications should be made for these awards.

\section{Scholarships at Foreign Universities, 1948-49}

THE British Council has been informed that scholarships for the academic year 1948-49 will be offered to students and graduates of British universities and colleges by the Governments of a number of foreign countries, including Belgium, Hungary, the Netherlands, Sweden (with the Swedish Institute for Cultural Relations) and the University of Teheran, Persia. The scholarships are normally intended for study on the postgraduate level. They cover in general the cost of tuition and maintenance and in some cases the cost of travel. Two scholarships have also been offered by the University of Cologne, and two by the University of Munster. Negotiations with the Control Commission are proceeding with regard to facilities for food and accommodation. Particulars can be obtained from the Controller of the Education Division, the British Council, 3 Hanover Street, London, W.1.

\section{University of London}

THe following appointments in the University of London have been announced :

Dr. L. J. Audus has been appointed to the Hildred Carlile chair of botany tenable at Bedford College as from October $1,1948$.

Dr. Eric' Boyland has been appointed to the University chair of biochemistry tenable at the Royal Cancer Hospital (Free) as from January 1, 1948. In 1935 he was appointed reader in biochemistry at the hospital.

The degree of Doctor of Science has been conferred on Sir Alfred C. G. Egerton, University professor of chemical technology in the Imperial College of Science and Technology.

\section{Royal Institute of Chemistry: Annual Meeting}

THe annual general meeting of the Royal Institute of Chemistry will be held during April 15-17 in Birmingham; this is the first occasion since the
Institute was founded that the meeting has been held in the provinces, and in honour of the occasion the Birmingham and Midlands Section has arranged a programme of scientific and social events. The Lord Mayor of Birmingham will give a civic welcome to the president (Mr. Roche Lynche). The programme includes an exhibition, "The Chemist in the Midlands", to be held in the Central Technical College, Birmingham, which will feature the training of the chemist, research, production, and the chemist and the public services. The exhibition will be open to the public. Prof. R. P. Linstead will give a lecture on "The Chemical Research Laboratory, Tedding. ton" ; and Prof. Maurice Stacey will speak on "The New Fluorocarbon Chemistry". Visits have been arranged to the University of Birmingham and the Barber Institute of Fine Arts, Messrs. Chance Bros. glassworks at Smethwick, and Messrs. Marston, Thompson and Eversheds brewery at Burton-on. Trent.

\section{Announcements}

LoRd Brabazon of TaRa has been elected president of the Royal Institution in succession to the late Lord Rayleigh.

A memorial Ceremony in honour of Max Planck is being arranged by the Max Planck Society for the Advancement of Science, the Academy of Science at Göttingen, the University of Göttingen, and; he German Physical Society in the British Zone of Germany, and will be held in the University of Göttingen on April 23 at 11 a.m. This date would have been Planck's ninetieth birthday.

An international symposium on the "Kinetics and Mechanism of Combustion and Ignition Reactions in the Gas Phase" will be held in Paris during April 26-May 1. This symposium is being organised by the Centre National de la Recherche Scientifique, with the assistance of the Rockefeller Foundation. Detailed information can be obtained from Prof. P. Laffitte, 12 rue Cuvier, Paris (5̇̀me).

DR. RIsto JuRva has been appointed director of the Finnish Institute for the Exploration of the Sea.

Dr. CyrIL J. W. Hooper has been appointed editor and general secretary of the Society of Dyers and Colourists. Dr. Hooper, who was born in London in 1913, received his education at Tottenham County School and the Royal College of Science, and eventually obtained the London degree of Ph.D. for work in physical chemistry. After some experience in industry, he became reader with Messrs. Charles Griffin and Co., Ltd., and recently he has been librarian and information officer in the Research and Development Department of Ascot Gas Water Heaters, Ltd.

A JorNT meeting of the British Society for the History of Science with the Science Masters' Associa. tion, the Historical Association and the Association of Women Science Teachers will be held on March 9 at 5 p.m. in the Lecture Theatre of the Science Museum, South Kensington, London, S.W.7, to discuss "The Place of the History of Science in Education". The speakers will include Dr. E. J. Holmyard (chairman); Dr. Sherwood Taylor; Mr. G. Fowles, formerly chairman of the Science Masters' Association; Mr. S. M. Toynə, chairman of council, Historical Association; and Miss L. E. Higson, secretary of the Association of Women Science Teachers, and there will be a general discussion. 